\title{
Splitsing van vennootschappen en fiscale begeleiding
}

\author{
Mr. Drs. J.W.H. van Zadelhoff
}

Na jarenlange aandrang vanuit wetenschap en praktijk is het sinds begin 1998 mogelijk om op een juridisch vereenvoudigde wijze over te gaan tot splitsing van een vennootschap'. Kon een splitsing tot dan toe in veel gevallen slechts worden uitgevoerd door middel van veelomvattende activa-/passivatransacties, door gebruikmaking van de figuur van de juridische splitsing kan dit worden teruggebracht tot één enkele rechtshandeling. Aangezien vanaf het begin duidelijk was dat een dergelijk herstructureringsinstrument in de praktijk niet bruikbaar zou zijn zonder adequate fiscale begeleiding. heeft de wetgever aansluitend aan de inwerkingtreding van de splitsingsregeling een fiscale begeleidingswet geïntroduceerd. Doel van deze bijdrage is om deze fiscale begeleidingswet nader onder de loep te nemen en te bezien welke fiscale voordelen kunnen worden behaald als het splitsingsinstrument wordt ingezet in het kader van de herstructurering van een concern. Vanwege het zeer specifieke karakter van het splitsingsinstrument zal worden aangevangen met een korte juridische introductie? ${ }^{2}$.

\section{Hoofdvormen van splitsing en juridische gevolgen}

De splitsingsregeling ${ }^{3}$ kent twee hoofdvormen van juridische splitsing: zuivere splitsing en afsplitsing. Daarnaast bestaat een aantal bijzonde-

Mr. Drs. J.W.H. van Zadelhoff RA is verbonden aan het Center for Company Law, Katholieke Universiteit Brabant, en doet onderzoek naar de fiscale, juridische en jaarrekeningrechtelijke aspecten van splitsing van vennootschappen. Hij is tevens wetenschappelijk adviseur van het vaktechnisch bureau van PricewaterhouseCoopers NV re variantent. Aangezien de twee hoofdvormen zowel in juridisch als in fiscaal opzicht sterk van elkaar verschillen, worden beide in deze paragraaf nader belicht.

\subsection{Zuivere splitsing}

De fïguur van de juridische splitsing wordt gekenmerkt door de overgang van het vermogen van de splitsende vennootschap naar twee (of meer) verkrijgende vennootschappen, waarbij de splitsende vennoolschap ophoudt te bestaan. Ter compensatie van het verlies van hun aandelen krijgen de aandeelhouders van de splitsende vennootschap naar rato aandelen toegedeeld in de verkrijgende vennootschappen. Zo worden in figuur 1 alle aandeelhouders van Euro NV na de splitsing van de vennootschap Euro NV aandeelhouder in zowel de nieuwe opgerichte vennootschap Deka NV als in de nieuw opgerichte vennootschap Femo NV.

\subsection{Afsplitsing}

In tegenstelling tot de figuur van de zuivere splitsing wordt de figuur van afsplitsing gekenmerkt door de overgang van een deel van het vermogen van de afsplitsende vennootschap naar één of meer verkrijgende vennootschappen ${ }^{5}$. De afsplitsende vennootschap blijft na de afsplitsing voortbestaan. Ter compensatie van het verlies van vermogen ontvangen de aandeelhouders van de afsplitsende vennootschap naar rato aandelen in de verkrijgende vennootschap. In het voorbeeld (figuur 2) blijven de oorspronkelijke aandeelhouders van Euro NV na de splitsing aandeelhouder in Euro NV en worden tevens aandeelhouder in Deka NV. 
aandeelhouders
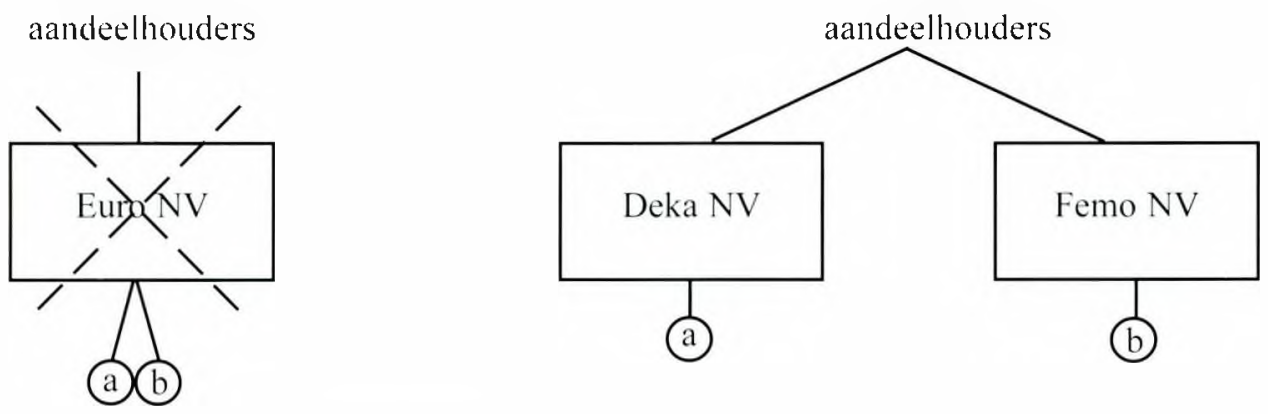

Fignur 1: a en brepresenteren twee afzonderlijke ondernemingen van Euro NV. Beide kumnen zowel wit losse activa en passiva, als uit éen of meer $100 \%$-deelnemingen hestaan

\subsection{Juridische aspecten ran splitsing}

De procedure voor juridische splitsing bestaat uit een aantal stappen. Zeer beknopt verloopt dit als volgt. Bij aanvang dient door het bestuur een uitgebreid splitsingsvoorstel met toelichting te worden opgesteld. Dit voorstel dient tezamen met drie voorafgaande jaarrekeningen te worden gedeponeerd bij het handelsregister; van deze deponering wordt melding gemaakt in een landelijk dagblad. Na de aankondiging dient een maand verzetstermijn in acht te worden genomen, waarna de algemene vergadering van aandeelhouders het definitieve splitsingsbesluit kan nemen. De dag na de verlijding van de notariële akte is de splitsing in juridische zin een feit.

Een van de grote voordelen van juridische splitsing van een vennootschap betreft de overgang van vermogen onder algemene tirel". Deze techniek troffen we al eerder aan bij het 'zusje' van de splitsing: de figuur van de juridische fusie. Ook bij de juridische fusie is er sprake van een overgang onder algemene titel, waardoor het vermogen automatisch ('van rechtswege') van de ene vennootschap volledig overgaat naar de

aandeelhouders

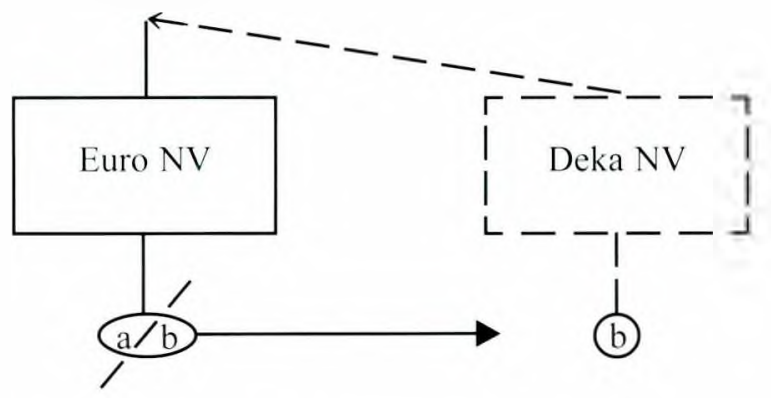

Figuur 2: Voorbeeld verkrijgende vennootschap. Belangrijk verschil met de figuur van de juridische fusie is echter dat bij de figuur van de juridische splitsing vermogen gesplitst wordt en vervolgens van rechtswege overgaat naar de verkrijgende vennootschap(pen).

Waar voorheen bij een activa- en passivatransactie de betreffende activa afzonderlijk dienden te worden geleverd en de betreffende crediteuren toestemming moest worden gevraagd. biedt de splitsingsregeling een geheel eigen instrumentarium. Hoe gaat dit in de praktijk nu in zijn werk?

In het splitsingsvoorstel dient een afzonderlijke paragraaf te worden opgenomen $w$ aarin alle activa en passiva van de vennootschap worden beschreven en vervolgens worden toegedeeld aan een van de verkrijgende vennootschappen. Bij een zuivere splitsing dienen de activa en passiva volledig te worden verdeeld, aangezien de splitsende vennootschap na de splitsing ophoudt te bestaan. Bij een afsplitsing kan daarentegen worden volstaan met een toedeling van de activa en passiva die worden afgescheiden: de resterende activa en passiva kunnen zonder problemen achterblijven bij de afsplitsende vennootschap.

Op het eerste gezicht lijkt de splitsingsregeling een zeer grote vrijheid te bieden: voor de overgang van onroerende zaken zijn immers geen afzonderlijke notariële akten noodzakelijk: de overgang van contracten kan zonder toestemming van de wederpartij geschieden en schulden kunnen zonder toestemming van de crediteuren overgaan naar een andere vennootschap. Dit maakt de splitsingsfiguren tot uiterst flexibel herstructureringsinstrument. Bij deze vermeende grote vrijheid moet echter een aantal kanttekeningen worden gemaakt. 
1 Voor bepaalde activa zullen toch nog extra handelingen moeten worden uitgevoerd om ze te laten overgaan op een andere vennootschap. Bij vergunningen zal bijvoorbeeld in veel gevallen toestemming moeten worden gevraagd aan het betreffende bestuursorgaan. Overdracht van compensabele verliezen is in geval van afsplitsing zelf's niet eens mogelijk. ongeacht de vaag of deze verliezen op de actiefzijde van de balans van de splitsende vennootschap zijn vermeld.

2 Wederpartijen en crediteuren kunnen tegen de splitsing in verzet ${ }^{*}$ komen indien voortzetting van het contract niet zou stroken met redelijkheid en billijkheid, dan wel indien de crediteur ernstig in zijn verhaalmogelijkheden zou worden beperkt.

3 Contracten met werknemers kunnen niet zomaar in vrijheid worden toegedeeld: deze contracten gaan dwingend over met de ondernemingsactiviteit die ten gevolge van de splitsing overgaat op een andere vennootschap".

4 Verwacht mag worden dat met name banken standaardclausules in hun financieringsarrangementen zullen opnemen. Deze clausules bieden in geval van een splitsing van de gefinancierde vennootschap een opzeggingsmogelijkheid, waardoor de betreffende bank zelfstandig kan besluiten tot voortzetting van de kredietrelatie ${ }^{\prime \prime}$.

5 De splitsingsregeling kent afzonderlijke kapitaal- en vermogensheschermingsmaatregelen waarvoor een accountantsverklaring noodzakelijk is ${ }^{11}$. Deze maatregelen houden onder meer in dat in geval van afsplitsing het resterende vermogen van de splitsende vennootschap voldoende moet zijn ter dekking van het aanwezige kapitaal en de verplicht aan te houden wettelijke reserves. Bij de verkrijgende vennootschap moet het ontvangen vermogen eveneens voldoende zijn ter dekking van het uitgegeven kapitaal en de verplicht aan te houden wettelijke reserves.

6 Als meest verstrekkende maatregel ter bescherming van crediteuren geldt de uithreiding van acansprakelijkheid van de betrokken vennootschappen. Alle vennootschappen die bij de splitsing zijn betrokken (de verkrijgende vennootschappen en in geval van afsplitsing ook de voorthestaande afsplitsende vennootschap) blijven na de toedeling van de diverse schulden tot een bepaald maximum geheel aansprakelijk voor de schulden die ten tijde van de splitsing bestonden. Dit betekent dat een crediteur die na afsplitsing geen verhaal kan halen op zijn debiteur naar een andere vennootschap kan stappen voor verhaal. De vennootschappen die zijn betrokken bij een splitsing kunnen hierdoor tot het verloop van de verjaringstermijnen voor vroegere schulden worden aangesproken. Volledige ontvlechting van de vemnootschappen is bij juridische splitsing derhalve niet mogelijk, tenzij alle crediteuren alsnog hiermee instemmen'?

Wat resteert is een beeld van juridische splitsing dat als herstructureringsinstrument grote voordelen biedt ten opzichte van de gecompliceerde activa-passivatransacties, doch ter bescherming van belanghebbenden tevens een uitgebreid palet van beschermingsmaatregelen bevat. Het gebruik van het splitsingsinstrument vergt dan ook een goede juridische afweging.

Niet minder belangrijk dan hiervoor genoemde juridische aspecten zijn de fiscale aspecten die kleven aan een splitsing. Hierover meer in de volgende paragrafen.

\section{Het cruciale vereiste voor fiscale begeleiding: "overwegend zakelijke motieven'}

\subsection{Aanzienlijke heffing zonder fiscale he'geleiding}

De splitsing van een vennootschap brengt zonder nadere fiscale begeleiding op twee niveaus aanzienlijke heffingen met zich mee. Op het niveau van de splitsende vennootschap dient $35 \%$ vennootschapsbelasting betaald te worden over stille reserves en goodwill die overgaan ter gelegenheid van de splitsing. Daarnaast dient de verkrijgende vennootschap $1 \%$ kapitaalsbelasting te betalen over de uitgifte van nieuwe aandelen en dient in geval van overgang van onroerende zaken $6 \%$ overdrachtsbelasting te worden betaald over de economische waarde van de verkregen onroerende zaken ${ }^{13}$.

Ook de aandeelhouder van de splitsende vennootschap ontkomt zonder nadere fiscale begeleiding niet aan hefling. Aangezien de ontvangst van nieuwe aandelen in de verkrijgende vennootschap bij deze aandeelhouder zou kunnen 
worden gekwalificeerd als 'dividend'. treedt bij hem inkomstenbelastingheffing op ${ }^{14}$.

\subsection{De fiscale begeleidingswet: het zakelijkheidsvereiste}

Het moge duidelijk zijn dat de aanwezigheid van de hiervoor genoemde heftingen een zeer belemmerende factor zou vormen voor een veelvuldig gebruik van de splitsingsfiguur. Dit zou de splitsingsregeling tot een dode letter in de wel maken. De wetgever heeft daarom besloten een fiscale faciliteit in het leven te roepen ${ }^{15}$. Deze faciliteit ("de fiscale begeleidingswet") maakt het onder strikte voorwaarden mogelijk een splitsing zonder heffing van belasting uit te voeren'th. Twee voorwaarden springen daarbij in het oog.

In de eerste plats mag de fiscale faciliteit nie' ten gevolg hebben dat bestaande fiscale claims verloren gaan. Bij de bespreking van de techniek van fiscale begeleiding zal hier nader op worden ingegaan. In de tweede plaats wordt de benodigde fiscale begeleiding slechts geboden indien aan de splitsing in oremegende mate zakelijke motieven ren grondslag liggen. Daarmee zijn we beland bij de kern van de fiscale begeleidingswet. De toekenning van de fiscale faciliteit is volledig alhankelijk van de aanwezigheid van zakelijke motieven. Zijn deze motieven niet. of niet in voldoende mate aanwezig. dan leidt de splitsing onvermijdelijk 101 de reeds eerder genoemde heffingen.

\subsection{De invalling vem her zukelijkheidsvereiste}

De introductie van het zakelijkheidsvereiste roept direct een aantal vragen op: Welke motieven kwalificeren nu als zakelijk? Hoeveel redenen moeten er zijn? Tellen andeehoudersmotievell ook mee' ?

Het is niet mogelijk deze vragen in hun algemeenheid te beantwoorden. De Staatssecretaris van Financiën heeft tijdens de parlementaire behandeling van de fiscale begeleidingswet meegedeeld dat de fiscus in de praktijk per atzonderlijke splitsingsiscasus zal boordelen of er sprake is van overwegend zakelijke motieven om tot splitsing over te gaan. In ieder geval zal de faciliteit niet worden toegekend in geval san misbruik of oneigenlijk gebruik. Dit biedt de liscus een ruime discretionaire ber oegdheid om al dan niet tot fiscale begeleiding over te gaan ${ }^{18}$.
Ondanks de vage bewoordingen bieden de parlementaire stukken tocl enige houvast bij de raag welke soorten splitsing een kans maken of juist generlei kans maken op fiscale begeleiding. Zo is opgemerkt dat slechts de zakelijke motieven van de splitsende vennootschap in de beoordeling zullen worden betrokken. Eventueel aanwezige zakelijke motieven van de aandeelhouder worden niet in aanmerking genomen. Dergelijke aandeelhoudersmotieven kunnen met name aanwezig zijn ingeval een aandeelhouder of samenwerkende groep van aandeelhouders doorshgggevende zeggenschap heeft in de splitsende vennootschap. Deze zeggenschap geeft de aandeelhouders de bevoegdheid om zelfstandig over een herstructurering te beslissen, hetgeen volgens de wetgever de kans op misbruik doet toenemen.

Voor de praktijk betekent dit dat een bedrijtseconomisch verantwoorde splitsing van een beursvennootschap met een zeer heterogene groep van wisselende aandeelhouders minder grote problemen zal opleveren voor fiscale begeleiding dan de splitsing ran een besloten vennootschap met een tweetal directeurengrootaandeelhouders. De fiscus zal in het laatste geval nauwkeurig nagaan of de aandeelhoudersbelangen wellicht de doorslag hebben gegeven bif de keuze voor het splitsingsinstrument. Dit laatste betekent overigens niet dat de aanwezigheid van een besloten aandeelhouderstelatie te allen tijde een gefacilieerde splitsing zal tegenhouden. Integendeel, wanneer bijvoorbeeld de relatie tussen de beide aandeelhouders dusdanig is verslechterd dat daardoor de bedrijfscontinuïteit in gevaar komt. kunnen de aandeelhoudersmotieven voor splitsing tevens zakelijke motieven voor de vennootschap vormen. Ergo: fiscale begeleiding is in zo"n geval zeker niet uitgesloten.

Enkele voorbeelden uil de parlementaire geschiedenis waarin sprake kan zijn $、$ an zakelijke motieven:

splitsing gericht op verhoging van de verhandelbaarheid van de aandelen:

splitsing op grond van de noodzaak tot duurzame rationalisatie of herstructurering van de activiteiten:

- splitsing gericht op verhoging van de beurswaarde door bijvoorbeeld de afslanking 101 kernactiviteiten;

splitsing gericht op de beperking van zakelijke risico`s. 
Bij ieder gegeven voorbeeld moet worden opgemerkt dat de concrete situatie doorslaggevend is voor de toekenning van de fiscale faciliteit.

Enkele voorbeelden waarin geen sprake is van zakelijke motieven:

splitsing van beleggings- en ondernemingsactiviteiten (met name gericht op de creatie van kasgeld-BV"s);

afsplitsing met het oog op de verkoop van een gedeelte van een onderneming:

- splitsing met het oog op de uitkoop van een of meer aandeelhouders.

Laatstgenoemd punt verdient nog enige toelichting met het oog op de inzet van splitsing bij bedrijfsoprolging. Aangezien bij de keuze voor juridische splitsing in de MKB-sfeer juist vaak de aandeelhouders zijn betrokken, zou fiscale begeleiding op de tocht kunnen komen te $\operatorname{staan}^{19}$. De zakelijke motieven van de vennootschap moeten immers de doorslag hebben gegeven bij de keuze voor juridische splitsing. De staatssecretaris heeft echter tijdens de parlementaire behandeling van de fiscale begeleidingswet gemeld dat zakelijk geïndiceerde bedrijfsopvolgingen niet zullen worden geblokkeerd. Juist in die gevallen zullen de bedrijfseconomische belangen van de vennootschap volgens hem bestaan uit het zeker stellen van de toekomst van de onderneming.

Aangezien er grote tinanciële belangen op het spel kunnen staan bij een splitsing, biedt de fiscale begeleidingswet de mogelijkheid om voorafgaande aan de splitsing zekerheid te verkrijgen omtrent de fiscale gevolgen van de splitsing ${ }^{20}$.

\section{De techniek van fiscale begeleiding}

Wanneer eenmaal is voldaan aan het zakelijkheidsvereiste ${ }^{2 !}$. kan de splitsing in beginsel zonder heffing plaatsvinden. Ter handhaving van de bestaande fiscale claims en ter voorkoming van misbruik gelden voor zowel de aandeelhouders als de betrokken vennootschappen bijzondere regels.

\subsection{De fiscule begeleiding van de beursandeelhouder ${ }^{22}$}

De aandeelhouders van een splitsende beursvennootschap ontvangen ter gelegenheid van de splitsing naar rato aandelen in de verkrijgende vennootschap. De fiscale begeleidingswet kwalificeert deze handeling als een 'vervreemding', waardoor or geen inkomstenbelastingheffing optreedt bij de aandeelhouders. De aandeelhouders ontvangen dus geheel belastingvrij de aandelen in de verkrijgende vennootschap.

Door deze belastingvrije 'uitdeling' zou voor de fiscus het gevaar ontstaan dat zij haar potentiële claim op de winstreserves van de splitsende vennootschap verloren ziet gaan. In normale gevallen treedt immers heffing op bij uitdeling van eigen vermogen boven het fiscaal gestort kapitaal: bij splitsing verdwijnt een deel van deze geclaimde winstreserves om soms terug te keren als kapitaal bij de verkrijgende vennootschap. Ter voorkoming van claimverlies bepaalt de fiscale begeleidingswet dat het fiscaal gestort kapitaal ${ }^{23}$ van de splitsende vennootschap naar rato wordt doorgeschoven naar de verkrijgende vennootschap $^{2-}$. Bij toekomstige terugbetaling van kapitaal/agio door een van de betrokken vennootschappen dient derhalve zeer nauwkeurig te worden beoordeeld of een gedeelte van het terug te betalen kapitaal wellicht fiscaal hesmet is. In dat geval leidt terugbetaling tot heffing van inkomstenbelasting. De fiscus behoudt door deze doorschuiftechniek in ieder geval indirect haar claim die zij voorafgaande aan de splitsing op de winstreserves van de splitsende vennootschap had.

Als de aandeelhouders van de splitsende vennootschap eenmaal belastingwij aandelen hebben ontvangen in de verkrijgende vennootschap. kunnen zij deze aandelen wederom zonder belastingheffing verkopen. De ontvangen aandelen vormen - net als alle andere aandelen normale vermogensbestanddelen waarvan verkoop in bijna alle gevallen zonder heffing kan plaatsvinden. Bij latere uitkering van dividend door de verkrijgende vennootschap wordt de aandeelhouder getroffen met heffing van inkomstenbelasting.

De fiscale begeleidingswet biedt hiermee een uitstekende mogelijkheid om beursvennootschappen te laten splitsen zonder dat heffing bij de aandeelhouders optreedt. Na de splitsing kan de aandeelhouder zelf kiezen of hij de aandelen in de beide vennootschappen wil behouden; bij een negatief oordeel is belastingvrije verkoop mogelijk. Het is met name voor beursvennootschappen nu fiscaal eenvoudiger geworden om terug te 
keren naar de kernactiviteit door gebruikmaking van het instrument van juridische splitsing?'?

Een kort woord nog over de mogelijkheid dat de aandelen in de splitsende vennootschap worden gehouden door een kleine hechte groep van aandeelhouders die samen doorslaggevende zeggenschap in de splitsende vennootschap bezitten ${ }^{26}$. Ook deze aandeelhouders kunnen belastingvrij aandelen in de verkrijgende vennootschap in ontvangst nemen. Als extra antimisbruikmaatregel is daarbij echter bepaald dat de aandeelhouders de verkregen aandelen in beginsel nier binnen drie jaren na de splitsing mogen vervreemden. Bij de splitsing van beursvennootschappen zal van deze doorslaggevende zeggenschap in het algemeen voor de individuele aandeelhouder geen sprake zijn, waardoor deze driejaarsbeperking geen gelding heeft.

\subsection{De fiscale begeleiding van de vennootschap}

Bij aanwezigheid van voldoende zakelijke motieven kan de vennootschap in het kader van een splitsing zonder heffing activa en passiva laten overgaan naar de verkrijgende vennootschap. In de sfeer van de fiscale begeleiding wordt daarbij een strikt onderscheid gemaakt tussen specifiek verhonden en niet-specifick verhonden fiscale rechten en plichten. De eerste categorie staat in direct verband met een activum of passivum; de laatste categorie staat in verband met de vennootschap zelf.

Teneinde alle vennootschapsbelastingclaims op - met name - de activa te behouden, bepaalt de fiscale begeleidingswet dat alle fiscale rechten en plichten die specifiek verbonden zijn aan deze activa en passiva mee overgaan naar de verkrijgende vennootschap. Fiscale boekwaarden worden doorgeschoven, afschrijvingstermijnen op panden gaan mee over, desinvesteringsclaims op machines gaan mee en eventuele potentiële sancties op aandelen vanwege eerder uitgevoerde reorganisaties gaan mee over.

De niet-specifiek rerhonden fiscale claims blijven in beginsel achter bij de (af)splitsende vennootschap. Als belangrijkste niet-specifiek verbonden recht kan worden genoemd de compensabele verliezen, waarop hierna zal worden ingegaan.
Naast het doorschuiven van de vennootschapsbelastingclaim vragen ook andere soorten belasting aandacht. De fiscale begeleidingswet bepaalt dat onroerende zaken vanuit de splitsende beursvennootschap zonder heffing van overdrachtsbelasting kunnen overgaan naar de verkrijgende vennootschap. Daarnaast kan de verkrijgende vennootschap zonder heffing van kapitaalsbelasting aandelen uitgeven aan de aandeelhouders van de splitsende vennootschap.

\subsection{Overgang van compensabele verliezen?'}

De hoofdregel dat niet-specifiek verbonden activa en passiva niet mee overgaan op de verkrijgende vennootschap betekende in geval van zuivere splitsing dat reeds opgebouwde compensabele verliezen verloren zouden gaan. Aangezien de wetgever dit niet wenselijk achtte, is hiervoor een bijzondere regeling getroffen. Let wel. deze regeling geldt slechts voor de fïguur van zuivere splitsing. Eventuele verliezen blijven in geval van afsplitsing altijd achter bij de afsplitsende vennootschap.

De bijzondere regeling bij zuivere splitsing werkt als volgt. Verliezen gaan in beginsel mee met de ondernemingsactiviteiten die de verliezen hebben veroorzaakt (causale toerekening). Pas als deze toerekening niet mogelijk is, dan kan verliestoedeling naar eigen inzicht plaatsvinden. De fiscus is in dat geval zeer alert op mogelijk misbruik bij de toedeling.

Als overgang van verliezen heeft plaatsgevonden naar een reeds bestaande verkrijgende vennootschap, dient deze vennootschap voor fiscale doeleinden een boekhoudkundig stelsel van winstsplitsing toe te passen. De verliezen die zijn verkregen ter gelegenheid van de splitsing kunnen slechts met winsten van de vermogensbestanddelen die eveneens in het kader van de splitsing zijn verkregen, worden gecompenseerd. Hierdoor wordt voorkomen dat verliezen van een gesplitste vennootschap worden 'misbruikt' ter compensatie van winsten van een bestaande verkrijgende vennootschap.

\section{Conclusie}

Juridische splitsing vormt een nieuw instrument dat kan worden ingezet bij de herstructurering van (beurs)concerns. Op juridisch vereenvoudigde wijze kunnen activa en passiva binnen 
een vennootschap van elkaar worden gescheiden en vervolgens aandelen worden toegekend. $\mathrm{Bij}$ het gebruik van het splitsingsinstrument moet terdege rekening worden gehouden met de bijzondere beschermingsmaatregelen die door de wetgever zijn getroffen.

De belangrijkste voorvraag bij de inzet van het splitsingsinstrument zal in de praktijk echter zijn of de splitsing zonder belastingheffing kan plaatsvinden. Het antwoord op deze vraag is afhankelijk van de aanwezigheid van zakelijke motieven. Als deze motieven in overwegende mate aanwezig zijn. dan bestaat een wettelijk recht op fiscale begeleiding. Deze fiscale begeleiding kent ter behoud van de bestaande fiscale claims en ter voorkoming van misbruik aanvullende voorwaarden. Opvallend is daarbij dat het recht op verliescompensatie slechts in geval van zuivere splitsing kan worden overgedragen aan een andere vennootschap.

Is eenmaal gekozen voor de inzet van het splitsingsinstrument en heeft men zekerheid over de fiscale begeleiding, dan biedt dit instrument een uitstekende vorm on tot herstructurering van een (beurs)concern over te gaan zonder nadelige fiscale consequenties. De praktijk zal moeten leren hoe het zakelijkheidsbegrip zich verder zal gaan ontwikkelen.

\section{T E R A T U U R}

Achterberg, M.P. van, (1997), Splitsing van rechtspersonen en de positie van de banken als schuldeisers en houders van zekerheden, De naamlooze vennootschap, nr. 7, pp.190-195.

Brandsma, R.P.C.W.M. en R.J. de Vries, (1997), Splits jij of fuseer ik (of omgekeerd?): de gevolgen van het wetsvoorstel inzake de fiscale begeleiding van juridische splitsing en fusie voor de betrokken lichamen, Fiscaal weekblad FED, p. 3345.

Buijn, F.K., (1998), Splitsing van rechtspersonen, civielrechtelijke aspecten, Tijdschrift Fiscaal ondernemingsrecht, nr. 35. p. 1.

Cornelissen, R.P.C., (1998), Fiscale begeleiding van de splitsing (zuivere splitsing en afsplitsing), Rechtsgeleerd magaziin Themis: tijdschrift voor publiek- en privaatrecht, nr. 8 , pp. 249-258

Dorresteijn, A.F.M. (red.), Juridische splitsing.

Essers, P.H.J. en J.W.H. van Zadelhoff, (1998), Fiscale begelelding van splitsing van vennootschappen, Tiidschrift Fiscaal ondernemingsrecht, nr. 35, p. 21.
Flipsen, P.H.M., M. Jakobsen en F.P.G. Potgens, (1998), Fiscale aspecten van juridische splitsing, Maandblad Belastingbeschouwingen, jrg. 67, nr. 3, p. 103.

Fortuin, P., (1999), In overwegende mate zakelijke overwegingen bij een civielrechtelijke splitsing, Maandblad Belastingbeschouwingen, nr. 2, p. 71.

Oostwouder, W., (1996), Juridische splitsing en de belangen van werknemers, Sociaal maandblad arbeid, jrg. 51, nr. 9, pp. $536-555$

Roest, J., (1997), Positie van werknemers en crediteuren bij juridische splitsing van rechtspersonen, Stichting \& vereniging, jrg. 11, nr. 6, pp.186-192

Simonis, P.H.M., (1997), Splitsing van rechtspersonen, regeling in het BW en voorstel fiscale begeleidingswet, Weekblad voor fiscaal recht, jrg. 126, nr. 6269, pp. 1663-169.

Slagter, W.J., (1999), De juridische splitsing in de praktijk met bijzondere aandacht voor de splitsingen bij Vendex en KPN, Ondernemingsrecht, nr. 2, pp. 38-42.

Solinge, G. van, (1997), Splitsing van verenigingen en stichtingen, Stichting \& vereniging, nr. 2, p. 29.

Wessels, B. (1997), Splitsing van het onsplitsbare?, Stichting \& vereniging, jrg. 11, nr. 6, pp.175-185

Zadelhoff, J.W.H. van, (1998a), Splitsing van vennootschappen, Tijdschrift Financieel Management, nr. 11/12, november/ december

Zadelhoff, J.W.H. van, (1998b), Splitsing, crediteurenbescherming en faillissement, Tijdschrift voor insolventierecht, jrg 4, nr. 7, p. 142.

Zanden, P.M. van der, (1999), Accountancy-aspecten van splitsing, Maandblad Belastingbeschouwingen, nr. 2, p. 108

Een uitgebreidere literatuurlijst is verkrijgbaar via j.w.h.vzadelhoff@kub.nl

\section{N O T E N}

1 De Nederlandse splitsingsregeling is overigens op alle privaatrechtelijke rechtspersonen van toepassing. Zie onder meer C. van Solinge (1997), Splitsing van verenigingen en stichtingen, Stichting \& Vereniging, nr. 2, p. 29.

2 Omwille van de omvang van dit artikel worden de splitsingsregeling en de fiscale begeleidingswet in hoofdlijnen besproken. Reacties naar aanleiding van dit artikel zijn van harte welkom via e-mail: j.w.h.vzadelhoff@kub.nl.

3 Men treft de splitsingsregeling aan in de artikelen 2: 334 a tot en met 334ii, BW.

4 De lezer realisere zich dat er in de praktijk op basis van 
de twee hoofdvormen en de bijzondere varianten talloze 'tussenvormen' van splitsing kunnen worden gecreëerd. Een van de tussenvormen betreft de overgang van vermogen naar een bestaande vennootschap. Voor meer praktijkgerichte casusposities verwijs ik onder meer naar mijn artikel Splitsing van vennootschappen in Tiidschrift Financieel Management, november/december 1998, de bundel Juridische splitsing onder redactie van A.F.M. Dorresteijn en naar F.K. Buijn, Splitsing van rechtspersonen, civielrechtelijke aspecten, Tiidschrift Fiscaal ondernemingsrecht, (1998) nr. 35, p. 1.

5 Afsplitsing van het gehele vermogen is slechts mogelijk indien een nieuw opgerichte dochtervennootschap fungeert als verkrijgende vennootschap. Deze variant staat beter bekend als de 'uitzakconstructie'.

6 Hierover uitgebreider: Wessels (1997), Splitsing van het onsplitsbare?, Stichting \& vereniging, jrg. $11 \mathrm{nr}$. 6, pp. 175-185.

7 In de volgende paragraaf komt het onderwerp 'compensabele verliezen' uitgebreider aan de orde.

8 Exact geformuleerd dienen crediteuren in verzet te komen en dienen contractpartijen aan de rechter een verzoek tot wijziging of ontbinding van het contract te doen.

9 Over de positie van werknemers verwijs ik naar: W. Oostwouder (1996), Juridische splitsing en de belangen van werknemers, Sociaal maandblad arbeid, jrg. 51 nr. 9, pp. 536555; J. Roest (1997), Positie van werknemers en crediteuren bij juridische splitsing van rechtspersonen, Stichting \& vereniging, jrg. 11 nr. 6, pp. 186-192.

10 Uitgebreider over de positie van de banken: M.P. Achterberg (1997), Splitsing van rechtspersonen en de positie van de banken als schuldeisers en houders van zekerheden, De naamloze vennootschap, nr. 7, pp. 190-195.

11 Hierover recent: P.M. van der Zanden (1999), Accountancy-aspecten van splitsing, Maandblad Belastingbeschouwingen, nr. 2, p. 108

12 Voor een compleet overzicht van alle crediteurenbeschermingsmaatregelen verwijs ik naar mijn artikel Splitsing, crediteurenbescherming en faillissement, Tiidschrift voor insolventierecht, jrg. 4 (1998) nr. 7. p. 142.

13 Overigens vindt op dit niveau geen heffing van vennootschapsbelasting plaats over de stille reserves van deelnemingen (ex. artikel 13, Wet $V p b$ 1969) vanwege de werking van de deelnemingsvrijstelling. Splitsing van beursholding brengt derhalve op het niveau van de splitsende houdster niet in alle gevallen fiscale afrekening met zich mede. Het probleem ligt in dat geval met name op het niveau van de aandeelhouder

14 Als de aandeelhouder kan worden gekwalificeerd als aanmerkelijk-belanghouder geldt voor hem afrekening tegen het ab-tarief van $25 \%$. Aandeelhouder-vennootschappen betalen belasting over de ontvangst van de nieuwe aandelen, afhankelijk van de status van hun splitsende deelneming (deelneming of belegging in de zin van artikel 13, Wet Vpb 1969).
15 Men treft de fiscale begeleidingswet verspreid in enkele belastingwetten aan: onder meer artikel 68a, Wet op de Inkomstenbelasting 1964 en artikel 14a, Wet op de Vennootschapsbelasting 1969.

16 Over deze wetgeving leze men R.P.C.W.M. Brandsma en R.J. de Vries, Splits jij of fuseer ik (of omgekeerd?): de gevolgen van het wetsvoorstel inzake de fiscale begeleiding van juridische splitsing en fusie voor de betrokken lichamen, Ficaal weekblad FED (1997), p. 3345; R.P.C. Cornelissen, Fiscale begeleiding van de splitsing (zuivere splitsing en afsplitsing), Rechtsgeleerd magaziin Themis: tijdschrift voor publiek- en privaatrecht (1998), nr. 8, pp. 249-258; P.H.J. Essers/J.W.H. van Zadelhoff, Fiscale begeleiding van splitsing van vennootschappen, Tijdschrift Fiscaal ondernemingsrecht (1998), nr. 35, p. 21; P.H.M. Flipsen/M. Jakobsen/F.P.G. Pötgens Fiscale aspecten van juridische splitsing, Maandblad Belastingbeschouwingen, jrg. 67 (1998), nr. 3, p. 103; P.H.M. Simonis, Splitsing van rechtspersonen, regeling in het BW en voorstel fiscale begeleidingswet, Weekblad voor fiscaal recht, jrg. 126 (1997), nr. 6269, pp. 1663-1669.

17 Over dit onderwerp zie recent $P$. Fortuin, In overwegende mate zakelijke overwegingen bij een civielrechtelijke splitsing, Maandblad Belastingbeschouwingen (1999), nr. 2, p. 71.

18 Opgemerkt moet worden dat de belastingplichtige de mogelijkheid wordt geboden om een negatieve beslissing van de fiscus voor te leggen aan de belastingrechter. Deze toetsingsmogelijkheid biedt in zekere mate enige bescherming tegen onjuiste of willekeurige beslissingen van inspecteurs

19 Recent heeft Slagter zich hierover verbaasd getoond: 'Ik vraag mij af of men in fiscale kringen niet te somber is, wanneer men meent dat aan een splitsing bij een "middenstandsconcern" geen zakelijke overwegingen ten grondslag plegen te liggen' (W.J. Slagter, De juridische splitsing in de praktijk met bijzondere aandacht voor de splitsingen bij Vendex en KPN, Ondernemingsrecht, 1999, nr. 2, pp. 38-42). Ik zou deze opmerking enigszins willen nuanceren. Het is niet zozeer de afwezigheid van zakelijke motieven, maar de aanwezigheid van aandee/houdersmotieven die consequenties kan hebben voor de fiscale begeleiding. Zodra de zakelijke motieven overwegen boven de aandeelhoudersmotieven zal de fiscus bereid zijn tot faciliëring. Aangezien de aandeelhouders in de MKB-sfeer per definitie nauw betrokken zijn bij de vennootschap, zal van de zijde van de fiscus nadrukkelijk worden bekeken of er geen sprake is van oneigenlijk gebruik van het splitsingsinstrument, daar waar een andere wijze van herstructurering normaliter tot afrekening zou leiden. Het moge duidelijk zijn dat dit in de praktijk aanleiding voor veel discussie met de fiscus zal zijn.

20 In de tijdsplanning voor een splitsing zal voor de behandeling door de inspecteur rekening moeten worden gehouden met een doorlooptijd van een tot enkele maanden.

21 Nauwkeuriger uitgedrukt: 'Wanneer de zakelijke motieven in een specifiek geval de doorslag hebben gegeven bij de keuze voor juridische splitsing...' 
22 Deze bijdrage beperkt zich tot de aandeelhoudersnatuurlijke personen die geen aanmerkelijk belang in de vennootschap hebben ( $<5 \%$ van de aandelen). Aanmerkelijkbelanghouders, ondernemers en vennootschappen die als aandeelhouder bij een splitsing zijn betrokken, kunnen - mits er sprake is van een zakelijke splitsing - eveneens een beroep doen op fiscale begeleiding. Vanwege hun afwijkende fiscale positie ten opzichte van 'gewone' beursaandeelhouders gelden voor hen echter andere regels met betrekking tot de 'doorschuiftechniek'.

23 Het begrip fiscaal gestort kapitaal geeft de ondergrens aan vanaf waar uitkeringen uit het eigen vermogen bij de aandeelhouder worden belast als inkomsten uit vermogen. Dit begrip hoeft overigens niet synchroon te lopen met het jaarre- keningtechnische begrip gestort kapitaal, onder meer vanwege de mogelijkheid van informele kapitaalstortingen.

24 Het oorspronkelijk op de aandelen van de gesplitste vennootschap fiscaal gestorte kapitaal wordt derhalve verdee/d over meerdere vennootschappen.

25 Ter voorkoming van misbruik kent de fiscale begeleidingswet de bepaling dat de verkrijgende vennootschap niet louter beleggingen en liquide middelen mag ontvangen. $\mathrm{Er}$ moet sprake zijn van een reële splitsing, anders zou het erg gemakkelijk zijn geworden om belastingvrij overtollige kasmiddelen terug te sluizen naar de aandeelhouder.

26 Deze situatie zal zich met name in de MKB-sfeer vaak voordoen. 